\title{
Issues of Legal Organization of the Patient-Health Care Professional Relationship
}

\author{
Dr.iur. Inga Kudeikina \\ Mg.iur. Karina Palkova \\ Riga Stradins University \\ karina.palkova@inbox.lv
}

\begin{abstract}
Nowadays increasing attention is paid to the issues of legal organization of the patient-health care professional relationship. One of the issues in this field is the institution of the rights and obligations of the patients and the medical practitioners. Cases when the doctor restricts the rights of the patient while fulfilling his duties or vice versa are rare. Interaction of the scope of rights and obligations of the patients and medical practitioners causes complicated situation. The author believes that solution to such situation is to be found in the human rights standards. The article discusses the issue regarding the grounds, on which the legal relationship of the patient and the health care professional are created, and how they are organized. The issues of the patient-health care professional relationship are viewed from the perspective of the human rights. Rights to life and health form the fundamental principle of the human rights, which is integrated in the national and international legal acts. The aim of the article is to provide insight to the role played by fundamental principle of the human rights, principles in the relationship of the patients and medical practitioners. Analyses show that human rights in relations between patients and health care professionals are absolute.
\end{abstract}

Keywords: patient rights, health care professionals' rights, human rights

\section{Introduction}

The issue of legal relationship between the patients and the medical practitioners becomes increasingly more important in Latvia. As the framework of the patient rights develops, new precedents in the patient-health care professional relationship are found in practice. The activities of both patients and medical practitioners are based on series of regulatory enactments, regulating the mutual legal relationship. Legal acts of national, European Union and international level serve as grounds for creation of the aforementioned legal relationship. Taking into account the rather complex scope of rights and obligations specified in the legal acts, this results in a contradicting notion of the enforcement of the rights and the limits of the discretion of the patient and the medical practitioner. In order to examine the essence of the issue, this thesis will review, what kind of relationship is being established between the patient and the health care professionals as a result of implementing the scope of rights and obligations stipulated in the regulatory enactments.

\section{Determining and restricting the scope of rights and obligations of the patient}

Upon adoption of the Law On the Rights of Patients in 2009 and the new practice of organization of cross-border health care, namely, by introducing the Directive (2011/24/ES) „On the application of patients' rights in cross-border healthcare” in Latvia in October 2013, significant changes have taken place in the field of medical law in Latvia. Eventually the changes encouraged development of the tendency of patient autonomy and weakening of the legal institution of the health care professional.

The most important special legal act of national level, which regulates the scope of the rights and obligations of the patients, is the Law On the Rights of Patients. The purpose of the law is to promote favourable relationships between a patient and the provider of health care services, facilitating active participation of the patient in his or her health care, as well as to provide him or her with an opportunity to implement and protect his or her rights and interests. ${ }^{1}$ The Law On the Rights of Patients includes such rights of the patient as rights to information, rights to refuse treatment or consent to treatment. ${ }^{2}$ 
The patient autonomy, the rights and obligations of the patient have been clearly defined and the purpose of promoting favourable relationships between the patient and the health care professional has been stated upon the Law On the Rights of Patients entering in force. On the one hand, the scope of the rights and obligations granted to the patient is narrow; on the other hand, the exclusive rights of the patient to freedom of treatment process can be restricted on the grounds of the current scope as well.

The Law On the Rights of Patients mentions the following obligations of the patient:

1. to take care of his or her health, if the health condition allows;

2. to become actively involved in medical treatment and to provide the attending physician the knowledge, which is necessary for ensuring medical treatment;

3. follow the internal rules of procedure of a medical treatment institution and the instructions of the medical practitioner;

4. to pay for the received health care services;

5. to respect the rights of other patients;

6. to present a personal identification document upon the request of the health care professional. ${ }^{1}$

It is important to note that the patient may directly infringe the rights of the health care professional upon enforcement of his/her rights and fulfilling or not fulfilling the duties.

Upon enforcement of the exclusive rights to refuse the treatment, the patient ignores the duties imposed by the law and simultaneously turns on the mechanism, activity of which is based on life and health. In such case the health care professional only has the duty to inform the patient of the potential consequences. On the condition that the decision of the patient remains the same after the health care professional has explained the situation, nevertheless the health care professional has the duty to encourage the patient to attend another doctor. Therefore the national regulatory enactments provide the patient with the rights to freely dispose of their health and life. However, these rights are restricted as well (Šulce-Rēvele, Līkanse 2013).

If the patient is unable to make the relevant decision on grounds of the health condition or age, the rights to act on behalf of the patient are transferred to the relatives of the patient. So in this case the exclusive rights of the patient to decide upon his or her health and life are transferred to third parties.

It follows from above that the patient has a rather vast array of rights and imposed obligations, which on the one hand gives the patient certain discretion, while on the other hand restricts his or her private rights such as rights to life, health, etc. The patient may refuse the treatment given a series of conditions, which will not always depend on the will of the patient.

\section{Discretion of the health care professionals within the framework of professional activity}

Regardless of the scope of rights and obligations granted to the patient, to a great extent making decisions regarding treatment depends on the health care professional as well. Contrary to the regulation of the rights and obligations of the patient, which is mostly determined by one legal act, the work of the health care professional is regulated by several regulatory enactments of the sector, that is, each profession of health care professionals has its own regulatory framework. At the same time it should be noted that the scope of obligations of the health care professionals in accordance with the specifics of the activities is included in the regulatory enactments regulating the procedure of providing health care services (Slokenberga, Gusarova,Lieljuksis, Mucins, Stanislavska, Saberte,Slisere, Taurina, 2015). Nevertheless the basic rights and obligations of the health care professionals are regulated by the national level regulatory enactment - the Medical Treatment Law.

Section 41 of the Medical Treatment Law stipulates the obligation of the doctor to provide information on the diagnosis of the illness in language that is understood by the patient. But before treatment consent of the patient to treatment has to be obtained. The doctor has the obligation to explain and inform the patient regarding potential consequences and 
complications of the disease. The doctor has to inform the patient regarding the potential side-effects of the prescribed medications or treatment methods.

In regard to the basic obligations in the work of health care professionals the independence of the doctor mentioned in the Medical Treatment Law has to be noted as well. Section 38 of the law stipulates that a doctor shall be independent in his or her professional activities. All doctors have the right to provide an opinion on the state of health and treatment of a patient. ${ }^{1}$ Therefore it shall be noted that, when speaking of the institution of the obligations of the health care professional, attention should be paid to the scope of restricting of the independence. It is important to find out what the independence of the doctor means, what are the limits of activity of a health care professional.

Considering the studies conducted at national level, independence of the health care professional means a scientifically substantiated professional activity in accordance with the code of conduct and choice of treatment for the benefit of the patient's health regardless of the economic or other interests of other persons or the doctor himself. ${ }^{2}$ However, on the other hand, there are the rights of the patient, which may contradict the scope of independence of the doctor. Such rights of the patient as rights to life and freedom should be noted here among others as well. The above shows that although independence of health care professional is integrated in the regulatory enactments of national level, its scope is limited and does not really give the person rights to a fully and indisputably independent activity. The burden of restrictions imposed on activities of health care professional "forces" the person to act in accordance with certain standards or an artificially created frame.

It is important that the mutual legal relationship of the patient and the health care professional is regulated by the public law, which essentially means determining of obligations with the purpose of balancing the interests of the individual and the society. Namely, this ensures protection of the individual against unjustified state intervention in his freedoms and guaranteeing equal rights of the individual.

On the other hand the legal relationship of the patient and the health care professional is based on the private interests of the parties. For example, the rights of the patient to confidentiality, qualitative treatment or careless treatment by health care professional, or the rights of the health care professional to independent actions during treatment process, obtaining of patient data, etc.

In the field of activity of private law the patient independently decides whether he wishes to use his rights, which, for instance, have been granted to the patient by the Law On the Rights of Patients. The aforementioned allows the persons to freely form legal relationship through mutual agreement at their discretion. The private law regulates the relationship on the grounds of equality, and mutual agreement is the most characteristic for of these rights. The main principles of the private law are independence and autonomy of the person, inviolability of private property and freedom of contract.

Therefore ideally the patient and the health care professional should reach an agreement during the treatment process, based on the rights and obligations of each party stipulated in the national regulatory enactments (Rosner, Berger, Kark, Bennet, 2000).

Besides, the discretion of each party stipulated in the national regulatory enactments should not restrict the activities of the other party.

But the outcome of the cooperation between the patient and the health care professional could result in a phenomenon. The health care professional has a discretion stipulated by the law, but he or she may act independently only so long as the exclusive and autonomous rights of the patient are not infringed.

Thus the national regulatory enactments are not able to ensure regulation of the relationship of the patient and the health care professional. The issue of implementing of the legal relationship of the patient and the health care professional and determining the scope of activity of the parties should be addressed from the perspective of the human rights.

1 Article 38 of the Medical Treatment Law, No 167/168, date 12.06.1997, as amended

2 Vilka I., (2013) Professional activities' of healthcare providers.[ Online] Avaliable: http://www.juristavards.lv/doc/260686-rstaprofesionala-brivibal (January, 2016) 
If we examine the content of the rights and obligations of the patients and the health care professionals specified in the national regulatory enactments, it shows that these are based on the principles of the basic human rights and freedoms, integrated in the European Union and international legal acts.

\section{Human rights aspect in patient-health care professional relationship}

The tendency shows, that relationship between patients and health care professionals more often are viewed from human rights perspective. It is noted that this approach helps to better understand the scope of patients and health care professionals' rights and obligations, how far they can apply particular rights. (Exster, 2002). Rights and duties of the parties at national level restrict each other. Human rights explain relations between patients and health care professionals from another perspective. New perspective gives new opportunity to solve the problem between too parties. At the same time it gives more freedom in relations between them. Human rights in patients and health care professional's relationship gives chance to expand the border of their activity (Gostin,1997).

The main principles of human rights that can be applied to patients and health care professional relationships include high standards of health. This standard shows both positive and negative guaranties in health system.

Main principles of human rights in patients and health care professionals' rights are founded in international and regional human rights norms and agreements. For instance, the International Covenant on Civil and Political Rights, the International Covenant on Economic, Social, and Cultural Rights, the European Convention on the Protection of Human Rights and Fundamental Freedoms, the European Social Charter and other regulations. ${ }^{1}$

Another source, which shows human rights and health interaction, is the Convention for the Protection of Human Rights and Dignity of the Europe's Convention for the Application of Biology and Medicine. The Convention shows that rights to private life, the rights to information, non-discrimination rights are protected. It should be noted that the European Social Charter ${ }^{2}$ Article 11 , shows the rights to the protection of health.

All these principles are protected by the national law. Because of implementation problems some transformation of general principles content is observed at national level. Latvian human rights and patients and health care professionals' relationships are mostly viewed from the civil rights perspective or social perspective. This approach is not effective way of problem solving because of the narrow approach (Hall, Bobinski,Orentlicher, 2005).

At the same time, the concept of human rights in patient care recognizes health care providers as important actors, whose rights must be respected both as a matter of principle and for the benefit of the patient. The relationship between patient and health care professionals' rights is critical. No doubt that health care professionals are unable to provide high-quality care unless their rights are respected and they can work under decent conditions with professional independence (Hervey, McHale, 2015). At the same time patients' rights focusing on exclusivity and their rights are central.

If national level regulations will be applied in relations between these two parties, situation is possible where the rights and duties of two parties can meet. In that case the rights and duties of one party will always restrict other parties' rights and duties which are mentioned in the national level regulations. But if relations will be viewed from the human rights perspective, exclusive right to life will be as general principle (Abraham, Lewis, 2000).

\section{Conclusion}

- Patients and health care professional enjoy the same human rights (rights of life, rights to information etc.).

- The patients and health care professionals' rights and duties which are mentioned in national level are too narrow and restrict social and professional activities of both parties.

1 Cohen, Ezer (2013), Human rights in patient care: A theoretical and practical framework. [Online] Avaliable: http://www.ncbi.nlm.nih.gov/pubmed/24421170 (January 15,2016) 
- Human rights in relations between patients and health care professionals are absolute.

\section{References:}

Abraham, J., Lewis, G. (2000). Regulating medicines in Europe: Competition, Expertise and Public health. Routlenge

Cohen, Ezer (2013), Human rights in patient care: A theoretical and practical framework. [Online] Avaliable: http://www.ncbi.nlm.nih.gov/pubmed/24421170 (January 15,2016)

Exster A. (3th ed.). (2002). Antwep-Oxford-New York:Intersentia. P.149

Gostin L.O, Lazzarini Z. (1997). Human rights and Public Health in the AIDS Pandemic. Oxford University Press, New York

Rosner F., Berger J.T., Kark P., Bennet A.J., (2000). Disclosure and Prevention of Medical Errors Arch Interm Med. P.20892092

Slokenberga,S., A.Gusarova, A.Lieljuksis,R. Mucins, Stanislavska O, Saberte L., Slisere D., Taurina L. (2015). Medical law. Latvia: Tiesu namu agentura

Šulce - Rēvele L., Līkanse D. (2013), Development of Latvian Pacients' rights. Journal Jurista vārds, № 41 (792) (online) Available: http://www.juristavards.Iv/doc/260694-pacientu-tiesibu-attistiba-latvija/ (January 12, 2016)

Tamara K.Hervey, Jean V.McHale, European Union Health Law, Cambridge university press, 2015, $160 p$

Vilka L., (2013) Professional activities' of healthcare providers. [Online] Avaliable: http://www.juristavards.Iv/doc/260686rsta-profesionala-briviba/ (January 16, 2016) 
